\title{
GMR
}

\section{Resistance to Helicoverpa armigera mediated by zingiberene and glandular trichomes in tomatoes for industrial processing}

\author{
J.F. Júnior ${ }^{1}$, J.T.V. Resende ${ }^{1}$, A.A. da Silva ${ }^{1}$, A. Gabriel1, A.R. Zeist ${ }^{2 *}$, R. \\ Favaro $^{1}$, D.A. Nascimento ${ }^{3}$, R.A. Zeist ${ }^{1}$ and C.K. Camargo ${ }^{1}$ \\ ${ }^{1}$ Universidade Estadual do Centro-Oeste, CEP 85040-080, Guarapuava - PR, \\ Brazil \\ ${ }^{2}$ Universidade Federal de Lavras, CEP 37200-000, Lavras - MG, Brazil \\ ${ }^{3}$ Faculdade Campo Real, CEP 85015-240, Guarapuava - PR, Brazil \\ Corresponding author: A.R. Zeist \\ E-mail: andre.zeist@bol.com.br
}

Genet. Mol. Res. 17 (2): gmr16039907

Received March 25, 2018

Accepted April 17, 2018

Published April 20, 2018

DOI: http://dx.doi.org/10.4238/gmr16039907

Copyright $\odot 2018$ The Authors. This is an open-access article distributed under the terms of the Creative Commons Attribution ShareAlike (CC BY-SA) 4.0 License.

ABSTRACT. The Helicoverpa armigera (Hübner) is a recent pest in Brazil, causing losses in tomato production in the Espírito Santo and Goiás states, in Brazil. A promising alternative to control this insect pest is the development of resistent tomato varieties. The breeding programs have aimed to introduce alleles of resistance present in the wild tomato accessions in the cultivated tomato. Thus, the objective of this study was to identify resistance to in tomato genotypes with high zingiberene leaf contents in the segregating population (F2) from the first backcross to Solanum lycopersicum 'Redenção' from $S$. habrochaites var. hirsutum accession 'PI-127826'. For this, the glandular trichomes present in the leaves of the selected genotypes were quantified and submitted to two antixenosis and one antibiosis test of resistance to $H$. armigera. The genotypes 'RVTZ-2011-pl\#117', 'RVTZ-2011-pl\#185', 'RVTZ-2011-pl\#335', and 'RVTZ-2011-pl\#503' showed a high density of type IV and type VI glandular trichomes. These genotypes showed higher 
resistance levels to $H$. armigera by antixenosis and antibiosis than the Redenção variety. The indirect selection for high zingiberene content and high density of type IV and type VI trichomes was effective to obtain tomato genotypes with higher levels of resistance to $H$. armigera

Key words: Plant breeding; Integrated pest management; Indirect selection; Allelo-chemical; Leaf trichomes

\section{INTRODUCTION}

Helicoverpa armigera (Hübner) (Lepidoptera: Noctuidae) is a highly polyphagous and widely distributed worldwide, living in tropical and temperate regions (Sharma et al. 2008). Recently, this species was considered a quarantine pest in Brazil. However, at the beginning of 2013, high infestations of H. armigera were reported in soybean crops in the states of Goiás and Bahia, and in cotton in the state of Mato Grosso. This was the first record of the occurrence of this pest on the American Continent (Czepak et al. 2013). Recently, H. armigera was reported causing damage in tomato crop in the four largest tomato-producing communities in the south of the Espírito Santo state (Pratissoli et al. 2015).

In tomato crops, females have the habit of ovipositing on the upper part of the plants, close to the youngest flowers and leaves, laying individual eggs, and in the abaxial face of the leaflets. Until the third instar, the young larva feeds mainly tender leaves, inflorescences, and fruits. In the last instar, the insect prefers to descend through the plant and penetrate the fruits to feed on the placenta and seeds. During this phase, the greatest losses occur in the crop, which can affect up to 55\% of the production (Tay et al. 2013; Usman et al. 2013).

In Brazil, the management of $H$. armigera still is in an initial establishment stage; but in countries where this pest is already widespread and causing economic losses for a longer time, the chemicals have been the main control tactic used; therefore, populations of $H$. armigera have developed resistance to various groups of insecticides. In addition, the exclusive use of these agrochemicals causes an increase in production costs, severe damage to the environment, and the health of rural workers and consumers (Czepak et al. 2013; Mamta et al. 2016; Roditakis et al. 2017).

In order to minimize the problems arising from the use of chemical insecticides, tomato-breeding programs have aimed to obtain resistant varieties to insect pests. Thus, alleles from the wild tomato accessions are responsible for the production of chemical compounds known such as allelochemicals and/or glandular trichomes. The selection for high content of allelochemicals and in some cases glandular trichomes has led to correlated responses in the increasing level of resistance in tomato pests (Resende et al. 2009; Baier et al., 2015; Lucini et al., 2015; Dias et al., 2016; Silva et al., 2016; Andrade et al., 2017).

The species of tomato Solanum habrochaites var. hirsutum has been reported as resistant to H. armigera (Talekar et al., 2006; Safuraie-Parizi et al., 2014; Muthukumaran, 2016) and other tomato pests. The resistance is associated to the high concentration of the zingiberene allelochemical (ZGB) in the leaves, which is a compound derived from secondary metabolism, produced and exuded by type IV and type VI glandular trichomes (Carter et al., 1989; Freitas et al., 2002). Higher content of zingiberene and higher densities of these types of trichomes have been correlated with the increase in the resistance levels of tomatoes via the mechanisms of antixenosis and antibiosis (Gonçalves et al., 2006; Oliveira et al., 2012; Lima et al., 2015; Fernandes et al., 2016).

Considering this information, the objective of this study was to verify the resistance to H. armigera caterpillar in tomato genotypes. These genotypes were selected for high zingiberene content in the leaves in the segregating population $\left(\mathrm{F}_{2}\right)$ of the first backcross for the tomato crop for 'Redenção' Solanum lycopersicum from accession 'PI-127826' of S. habrochaites var. hirsutum. 


\section{MATERIAL AND METHODS}

\section{Location of experiment conduction}

The experiment was conducted at the Olericulture Sector and the Laboratory of Plant Physiology/Horticulture, Department of Agronomy, State University of the Center-West CEDETEG Campus, UNICENTRO, Guarapuava-PR, latitude $25^{\circ} 23^{\prime} 00^{\prime \prime} \mathrm{S}$ and longitude $51^{\circ} 29^{\prime} 38.50^{\prime \prime} \mathrm{W}$, and 1,024 meters of altitude.

\section{Acquisition of genotypes with high zingiberene content and high density of type IV and type VI glandular trichomes}

The population of $F_{1}$ and $F_{2}$ were obtained from the interspecific crossing ('Redenção' $\times$ 'PI-127826'). The commercial Redenção variety has a determined growth habit, with industrial processing characteristics, resistance to Gemini virus and tospo virus, low contents of zingiberene in its leaves, and low density of type IV and type VI glandular trichomes (Ferraz et al., 2003). 'PI-127826' is a wild accession of the species Solanum habrochaites var hirsutum, with high contents of zingiberene in the leaves, high density of type IV and type VI glandular trichomes, and resistance to the tomato pests (Carter et al., 1989; Freitas et al., 2002).

In the population $\mathrm{F}_{2}$, (Lima et al. 2015) selected plants with high contents of zingiberene in the leaves, which were used as a source of pollen for crossing with the Redenção variety and obtaining the generation $F_{1}$ from the first backcrossing. From self-fertilization of plants $F_{1} R_{1}$, we obtained the segregating population $\left(\mathrm{F}_{2}\right)$ of the first backcrossing for the Redenção variety used in the present study.

For the evaluation of the zingiberene content in the leaves, we used 600 plants from the $\mathrm{F}_{2} \mathrm{RC}_{1}$ population, besides 40 plants of each of the parents were transplanted into pots with a capacity of $2 \mathrm{dm}^{3}$ and kept in the greenhouse. At 35 days after transplanting, six leaf discs of young leaflets from the middle part of the fully expanded plants were collected, using a cutter, and placed in test tubes, totaling $6 \mathrm{~cm}^{2}$ of each plant. To extract the zingiberene, $2 \mathrm{~mL}$ of PA distilled hexane was added to the leaf discs in test tubes and shaken for 40 seconds on a vortex tube shaker. Then, for the quantification, the samples were subjected to spectrophotometer reading (Cary $100 \mathrm{UV}$-Vis) with absorbance at the wavelength of $270 \mathrm{~nm}$.

The selection was made based on absorbance values of the four genotypes with high levels of zingiberene ('RVTZ-2011-pl\#117', 'RVTZ-2011-pl\#185', 'RVTZ-2011-pl\#335', and 'RVTZ-2011-pl\#503'). These genotypes were cloned via axillary shoot proliferation in expanded polystyrene trays with 128 cells. These tray cells were filled with a commercial substrate containing a blasted pine bark base for multiplication and used in resistance tests to $H$. armigera. The trays containing the shoots were kept in a greenhouse and irrigated manually until the roots formed and the vegetative structures developed. Seeds of the Redenção variety were sowed at the same time as the clones and fifteen days in before sowing the accession 'PI$127826^{\prime}$ due to the difference in germination, emergence, and growth.

The genotype characterization regarding the density of glandular trichomes was performed by collecting 40 50 days old, young and expanded leaflets from the medial part of three plants of each genotype grown in the greenhouses. For each leaflet collected, four blades of the abaxial (AB) and adaxial (AD) sides of the leaf surface were made with the aid of colorless cosmetic enamel and ground graphite. The slices were analyzed by scanning the electron microscopy (SEM) (Vega3 Tescan XM) HV at $5 \mathrm{kv}$, of $1 \mathrm{~mm}^{2}$ to obtain images. Then, the average density and type of trichomes were evaluated on the abaxial and adaxial faces with $1 \mathrm{~mm}^{2}$ the leaflets, according to Luckwill (1943) and Kraus and Arduim (1997). 


\section{Resistance testing to $H$. armigera}

The insects used in the tests were obtained from a mass production of the Bug Agentes Biologicos ${ }^{\circledR}$. The eggs were kept in plastic containers $(250 \mathrm{~mL})$ until the larvae hatched. Then, we transferred the larvae to $50.0 \mathrm{ml}$ plastic cups, containing an artificial diet prepared according to Greene et al. (1976) until reaching the pupal stage. Later, the pupae were removed from the cups and placed in $100 \mathrm{~mm}$ PVC cages, lined with paper towel and covered with voile fabric. Inside the cages was a piece of cotton soaked with $10 \%$ honey solution to feed the moth. The creation was maintained in air-conditioned, BOD incubator $\left(25 \pm 3^{\circ} \mathrm{C}\right.$, relative humidity of $70 \pm 5 \%$, and photo-phase of 14 hours).

The no-choice preference test was set up approximately 30 days after the transplanting of the seedlings into the greenhouse. Therefore, similar leaflet sizes from the upper-middle part of the tomato plants were placed in paper bags with the proper identification of genotype and replicate. In the laboratory, $30 \mathrm{~mm}$ diameter leaf discs were collected from the leaflets using a cutter. The leaf discs were placed in Petri dishes of $6 \mathrm{~cm}$ in diameter, lined with foam moistened with distilled water. Onto each leaf disc was release a newly hatched larva of $H$. armigera. The plates were closed and maintained in a BOD incubator $\left(25 \pm 3{ }^{\circ} \mathrm{C}\right.$, relative humidity of $70 \pm 5 \%$, and photo-phase of 14 hours). The experiment was organized in a completely randomized design, with six treatments and 20 replications.

We evaluated the intensity of leaf damage and the percentage of leaf attacked using the scale of scores proposed by Labory et al. (1999), as follows: intensity of leaf damage: 0-no damage; 1-small lesions (0.1 to $5 \%$ damage); 2 -small and non-coalescing lesions (5.1\% to 20\% damage); 3 -medium to large lesions (20.1 to $50 \%$ damage); 4-large and coalescing lesions (50.1\% to 80\% damage); and 5-plants totally destroyed (over $80 \%$ of damage). Percentage of leaflets attacked: 0 -no leaflets attacked; $1-0.1$ to $5 \%$ of leaflets attacked; 2 $5.1 \%$ to $20 \%$ of leaflets attacked; $3-20.1$ to $50 \%$ of leaflets attacked; $4-50.1$ to $80 \%$ of leaflets attacked; and 5 -more than $80 \%$ of damaged leaflets. The evaluations were conducted 24 and 48 hours' post-release by five evaluators previously trained.

The free-choice preference test was set up by using leaflet of the upper part of the plant approximately 35 days after the transplanting of the seedlings. In the laboratory, these were placed in $6 \mathrm{~cm}$ diameter Petri dishes, containing a cotton layer moistened with distilled water. In each plate, two leaf discs of $3 \mathrm{~cm}$ in diameter each were placed with the adaxial side facing upwards, connected by a continuous transparent acrylic tape, which allowed the insect to free choice between the two leaves. In the middle portion of the tape was released a first instar larva of $H$. armigera. The plates were maintained in the BOD incubator $\left(25 \pm 3^{\circ} \mathrm{C}\right.$, relative humidity of $70 \pm 5 \%$ and 14-hour photophase) and the evaluation was performed 24 hours after releasing of the larvae. The experimental design was a completely randomized design with six treatments and 20 replications.

The antibiosis test was set up on $6 \mathrm{~cm}$ diameter Petri dishes, lined with cotton moistened with distilled water, where a leaflet of each of the genotypes was placed approximately 40 days after the transplant. Onto each leaflet was transferred one first-instar $H$. armigera from the creation of maintenance, using a fine-bristled brush. The leaflets of the genotypes were systematically changed until the larvae changed to the pre-pupal stage. The plates were closed and maintained in a BOD incubator $\left(25 \pm 3{ }^{\circ} \mathrm{C}\right.$, relative humidity of $70 \pm 5 \%$ and 14-hour photophase). The experimental design was completely randomized, with 30 replications.

The following biological parameters were evaluated: larval phase duration, larval length, larval viability, leaf area consumed, and duration of pupal stage, pupal viability and sex ratio. 


\section{Statistical analysis}

The data collected were submitted to the Shapiro Wilk test of normality and Bartlett's test for homogeneity. In order to meet these assumptions, the data referring to preference tests with non-choice and antibiosis were transformed into $\sqrt{ }(X+0.5)$. Analysis of variance was performed, and the means were compared by the Tukey test at 5\% probability using the SISVAR software (Ferreira, 2008). Data on bioassays with a chance of choice were analyzed by the chi-square test $(\mathrm{P} \leq 0.05)$, testing the hypothesis of equality between observed and expected frequencies of individuals who were going to each treatment.

\section{RESULTS}

The four tomato genotypes ('RVTZ-2011-pl\#117', 'RVTZ-2011-pl\#185', 'RVTZ-2011-pl\#335', and 'RVTZ2011-pl\#503') selected for high levels of zingiberene did not differ among each other in the absorbance values, and higher absorbance values were observed when compared to the Redenção variety, but smaller when compared to the wild progenitor 'PI-127826' (Table 1).

Table 1. Zingiberene content and number of type IV and type VI glandular trichomes on the abaxial (AB) and adaxial (AD) faces on leaflets of tomato genotypes $\mathrm{F}_{2} \mathrm{RC}_{1}$, 'Rendeção' and 'PI-127826'.

\begin{tabular}{|c|c|c|c|c|c|c|}
\hline \multirow[t]{2}{*}{ Genotypes } & \multirow[t]{2}{*}{ Zingiberene content } & \multicolumn{5}{|c|}{ Glandular trichomes $\left(\mathrm{mm}^{2}\right)$} \\
\hline & & \multicolumn{2}{|c|}{ Type IV } & \multicolumn{2}{|c|}{ Type VI } & Type IV+VI \\
\hline 'RVTZ-2011-pl\#117' & $0.3784 \mathrm{~b}$ & $65.66 \mathrm{~b}$ & $26.91 \mathrm{~b}$ & $6.66 \mathrm{bc}$ & $5.00 \mathrm{a}$ & $104.23 \mathrm{~b}$ \\
\hline 'RVTZ-2011-pl\#335' & $0.4607 \mathrm{~b}$ & $40.00 \mathrm{c}$ & $56.75 \mathrm{a}$ & $4.58 \mathrm{c}$ & $5.41 \mathrm{a}$ & $106.74 \mathrm{~b}$ \\
\hline 'RVTZ-2011-pl\#503' & $0.4015 \mathrm{~b}$ & $59.91 \mathrm{~b}$ & $32.33 \mathrm{~b}$ & $8.41 \mathrm{~b}$ & $4.66 \mathrm{a}$ & $106.31 \mathrm{~b}$ \\
\hline 'Redenção' & $0.0687 \mathrm{c}$ & $0.00 \mathrm{~d}$ & $1.60 \mathrm{c}$ & $0.50 \mathrm{~d}$ & $0.00 \mathrm{~b}$ & $2.10 \mathrm{c}$ \\
\hline
\end{tabular}

(Note: *Means followed by the same letter in the column did not differ statistically from each other by the Tukey test ( $\mathrm{p} \leq 0.05)$.)

A greater number of type IV and type VI glandular trichomes were observed in the abaxial and adaxial faces for these genotypes; the total number of glandular trichomes (IV + VI + AB + AD) were higher compared to the Redenção variety and lower when compared to the accession 'PI-127826', except the genotype 'RVTZ2011-pl\#335' which is not different from 'PI-127826' in the number of type IV trichomes of the adaxial side of the leaflets. On the adaxial side, the four genotypes selected also did not differ from the 'PI-127826' accession in relation to the type VI trichomes (Table 1).

The no-choice preference test, genotypes with high levels of zingiberene and high-density type IV and type VI glandular trichomes presented lower visual notes of leaflet damage intensity compared to the Redenção variety, and they were higher when compared to the accession 'PI-127826', except the genotype 'RVTZ-2011$\mathrm{pl} \# 335$ ', which did not differ from 'PI-127826' in the evaluation at 24 hours after releasing the H. armigera. Regarding the intensity of leaf damage evaluation, after 48 hours of releasing the larva, no differences were observed between the selected genotypes compared to the 'Redenção' progenitors and 'PI-127826' (Table 2).

For the percentage of the attacked leaflet evaluated in this test, the four genotypes selected for high zingiberene contents presented lower visual scores compared to the Redenção variety and they were higher when compared to the 'PI-127826', except for the genotype 'RVTZ-2011-pl\#335', which did not differ from the 'PI-127826' in the evaluation 24 hours after releasing the larva. In the 48-hour evaluation, no significant differences were observed between the selected genotypes and the 'PI-127826' accession, but these genotypes, as well as 'PI-127826', presented lower scores for the percentage of the leaflet attacked in relation to the Redenção variety (Table 2). 
Table 2. Leaflet damage intensity and attack percentage 24 and 48 hours after releasing $H$. armigera onto the adaxial side of tomato leaflets from genotypes $\mathrm{F}_{2} \mathrm{RC}_{1}$, 'Redenção' and 'PI-127826'.

\begin{tabular}{|c|c|c|c|c|c|}
\hline \multirow{2}{*}{ Genotypes } & \multirow{2}{*}{ Zingiberene content } & \multicolumn{2}{|c|}{ Intensity of damage } & \multicolumn{2}{|c|}{ Attack percentage } \\
\hline & & 24 hours & 48 hours & 24 hours & 48 hours \\
\hline 'RVTZ-2011-pl\#185' & $0.3873 \mathrm{~b}$ & $2.10 \mathrm{~b}$ & $2.25 \mathrm{a}$ & $1.80 \mathrm{~b}$ & $1.54 \mathrm{~b}$ \\
\hline 'RVTZ-2011-pl\#503' & $0.4015 b$ & $2.23 \mathrm{~b}$ & $1.76 \mathrm{ab}$ & $1.73 \mathrm{~b}$ & $1.73 \mathrm{~b}$ \\
\hline 'Redenção' & $0.0687 \mathrm{c}$ & $3.00 \mathrm{a}$ & $2.20 \mathrm{ab}$ & $2.30 \mathrm{a}$ & $3.03 \mathrm{a}$ \\
\hline 'PI-127826' & $0.7835 \mathrm{a}$ & $1.40 \mathrm{c}$ & $1.50 \mathrm{~b}$ & $1.30 \mathrm{c}$ & $1.38 \mathrm{~b}$ \\
\hline
\end{tabular}

(Note : *Means followed by the same letter in the column did not differ statistically from each other by the Tukey test ( $\mathrm{p} \leq 0.05)$.)

A lower percentage of $H$. armigera were observed on the leaflet discs of 'PI-127826' in relation to genotypes ('RVTZ-2011-pl\#117', 'RVTZ-2011-pl\#185', 'RVTZ-2011-pl\#335', and 'RVTZ-2011-pl\#503') with high levels of zingiberene and high density of glandular trichomes and the Redenção variety (Figure 1A) in the free-choice preference test. In contrast, the Redenção variety showed a higher percentage of choice in comparison with these four selected genotypes and with the accession 'PI-127826' (Figure 1B).
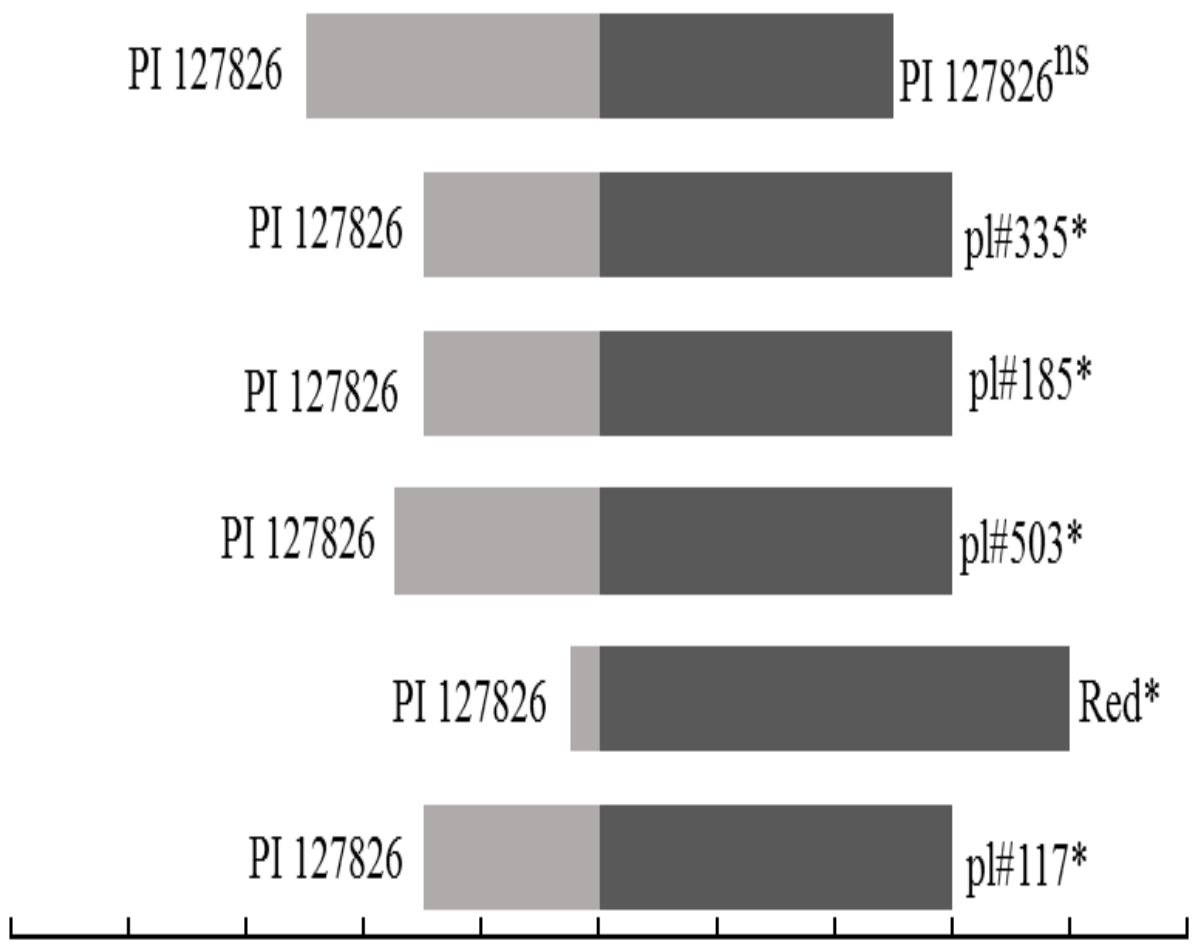

(A) 


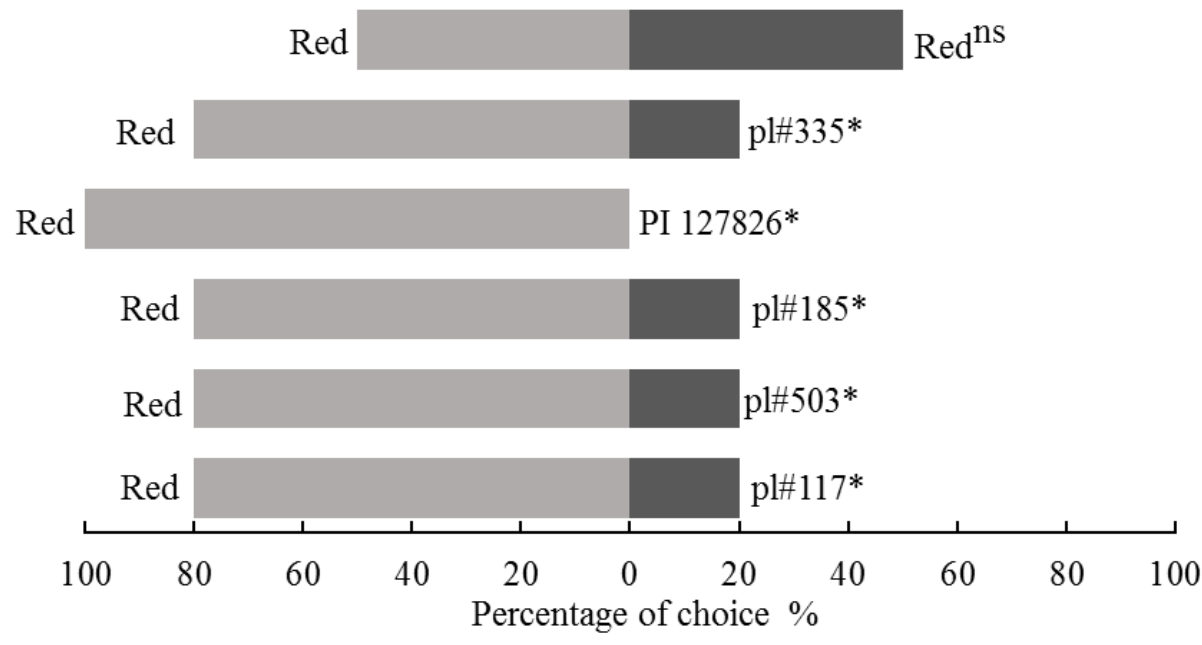

(B)

Figure 1. Percentage of choice (\%) made by the H. armigera in relation to the tomato genotypes. A) Comparison of the accession 'PI127826' with the genotypes ('RVTZ-2011-pl\#117', 'RVTZ-2011-pl\#185', 'RVTZ-2011-pl\#335', and 'RVTZ-2011-pl\#503'), selected for high levels of zingiberene and the Redenção (Red) variety. B) Comparison of the Redenção variety with the genotypes selected for high levels of zingiberene and the 'PI-127826'. $\left({ }^{\mathrm{n}}\right)$ Means do not differ statistically from each other; $(*)$ Means differ statistically from each other $(\mathrm{p} \leq 0.05)$

The antibiosis test showed $H$. armigera fed with leaflets of the genotypes 'RVTZ-2011-pl\#117' and 'RVTZ2011-pl\#335', with high levels of zingiberene, had a longer larval phase when compared to the Redenção variety. However, the genotypes 'RVTZ-2011-pl\#185' and 'RVTZ-2011-pl\#503' did not differ from the Redenção variety. The larvae fed with leaflets of wild accession 'PI-127826' did not complete the larval stage (Table 3).

Table 3. Zingiberene contents (absorbance at $270 \mathrm{~nm}$ ), length of larval phase (days), larval length (mm), mass (g), larval viability (\%), and leaf area consumed $\left(\mathrm{cm}^{2}\right)$ of tomato from genotypes $\mathrm{F}_{2} \mathrm{RC}_{1}$, 'Redenção' and 'PI-127826'.

\begin{tabular}{|c|c|c|c|c|c|c|}
\hline Genotypes & $\begin{array}{l}\text { Zingiberene } \\
\text { contents }\end{array}$ & $\begin{array}{l}\text { Lenght of } \\
\text { larval phase }\end{array}$ & Larval lenght & Mass & Larval viability & $\begin{array}{l}\text { Leaf area } \\
\text { consumed }\end{array}$ \\
\hline 'RVTZ-2011-pl\#117' & $0.3784 \mathrm{~b}$ & $35.00 \mathrm{a}$ & $8.13 \mathrm{c}$ & $0.054 \mathrm{c}$ & $10.00 \mathrm{~b}$ & $38.98 \mathrm{bc}$ \\
\hline 'RVTZ-2011-pl\#185' & $0.3873 \mathrm{~b}$ & $29.75 \mathrm{~b}$ & $9.59 \mathrm{~b}$ & $0.086 \mathrm{~b}$ & $13.33 \mathrm{~b}$ & $64.23 \mathrm{~b}$ \\
\hline 'RVTZ-2011-pl\#335' & $0.4607 \mathrm{~b}$ & $39.80 \mathrm{a}$ & $10.96 \mathrm{~b}$ & $0.094 \mathrm{~b}$ & $16.66 \mathrm{~b}$ & $52.99 \mathrm{~b}$ \\
\hline 'RVTZ-2011-pl\#503' & $0.4015 b$ & $26.30 \mathrm{~b}$ & $13.14 \mathrm{~b}$ & $0.089 \mathrm{~b}$ & $20.00 \mathrm{~b}$ & $56.47 \mathrm{~b}$ \\
\hline 'PI-127826' & $0.7835 \mathrm{a}$ & - & $5.71 \mathrm{c}$ & $0.023 \mathrm{c}$ & - & $0.023 \mathrm{c}$ \\
\hline
\end{tabular}

(Note: *Means followed by the same letter in the column did not differ statistically from each other by the Tukey test $(\mathrm{p} \leq 0.05)$.)

The larvae fed a leaflet of 'PI-127826' and genotype 'RVTZ-2011-pl\#117' with high zingiberene contents presented lower length and mass when compared to the other genotypes. When fed with the other selected genotypes 'RVTZ-2011-pl\#185', 'RVTZ-2011-pl\#335', 'RVTZ-2011-pl\#503', the larvae had smaller length and mass compared to the caterpillar fed with the Redenção variety (Table 3).

Larval viability was lower for all genotypes with a high content of zingiberene and high density of type IV and type VI trichomes in contrast to the Redenção variety. All larvae fed with the 'PI-127826' genotype died before completing the larval stage (Table 3 ). 
The total leaf area consumed by the caterpillars was higher in the Redenção variety than the other genotypes. The genotypes selected for high zingiberene contents were more consumed by larvae than 'PI-127826', except for the genotype 'RVTZ-2011-pl\#117' that did not differ from wild accession (Table 3).

During the duration of the pupal stage, the $H$. armigera fed with genotypes with different zingiberene content did not differ from each other. The insects fed with leaflets from the wild access 'PI-127826' did not enter in this biological development stage (Table 4).

The viability of the pupae was lower for the two genotypes 'RVTZ-2011-pl\#117' and 'RVTZ-2011-pl\#185' compared to the other two genotypes 'RVTZ-2011-pl\#335' and 'RVTZ-2011-pl\#503' with high levels of zingiberene. Although they presented lower averages for this parameter, the genotypes 'RVTZ-2011-pl\#335' and 'RVTZ-2011-pl\#503' did not differ from Redenção variety (Table 4).

In the adult stage, the sexual ratio was lower for the selected genotypes compared to the Redenção variety. Insects fed with leaves from the wild accession, which had higher levels of zingiberene, did not reach adult stage (Table 4).

Table 4. Zingiberene contents (absorbance at $270 \mathrm{~nm}$ ), duration of pupal stage (days), pupa viability (\%), and sex ratio $(\& / \overbrace{}^{\top})$ of tomato from genotypes $\mathrm{F}_{2} \mathrm{RC}_{1}$, 'Redenção' and 'PI-127826'.

\begin{tabular}{lcccc}
\hline Genotypes & Zingiberene contentes & $\begin{array}{c}\text { Duration of pupal } \\
\text { stage }\end{array}$ & Pupa viability \\
\hline 'RVTZ-2011-pl\#117' & $0.3784 \mathrm{~b}$ & $17.00 \mathrm{a}$ & $66.66 \mathrm{~b}$ & $25.00 \mathrm{~b}$ \\
\hline 'RVTZ-2011-pl\#185' & $0.3873 \mathrm{~b}$ & $16.60 \mathrm{a}$ & $75.00 \mathrm{~b}$ & $80.00 \mathrm{a}$ \\
\hline 'RVTZ-2011-pl\#335' & $0.4607 \mathrm{~b}$ & $15.00 \mathrm{a}$ & $83.33 \mathrm{a}$ & $33.00 \mathrm{~b}$ \\
\hline 'RVTZ-2011-pl\#503' & $0.4015 \mathrm{~b}$ & $14.40 \mathrm{a}$ & $92.52 \mathrm{a}$ & - \\
\hline 'Redenção' & $0.0687 \mathrm{c}$ & $15.30 \mathrm{a}$ & - & -
\end{tabular}

(Note: *Means followed by the same letter in the column did not differ statistically from each other by the Tukey test ( $\mathrm{p} \leq 0.05$ ).)

\section{DISCUSSION}

The genotypes selected in the segregating population of the first backcrossing for the Redenção variety have lower zingiberene content than the wild parental 'PI-127826'. These are classified as high (absorbance above 0.3 in reading at $270 \mathrm{~nm}$ ) and sufficient to increase the level of resistance of the tomato to arthropod pests (Glas et al., 2012; Lima et al., 2011).

The genotypes selected for high zingiberene contents also showed a high density of type IV and type VI glandular trichomes, on both faces of the leaflets. This shows that most of the zingiberene contents in the tomato leaflets are released by the glands contained at the end of these types of trichomes. Maluf et al. (2001), Freitas et al. (2002), Gonçalves et al., (2006), Bleeker et al., (2012), and Oliveira et al., (2012) also attributed the presence of this allelochemical to the type IV and type VI glandular trichomes.

In both free-choice and no-choice preferences tests, genotypes selected for high levels of zingiberene and with a high density of type IV and type VI glandular trichomes were less preferred by H. armigera, which confirms the action of these factors in increasing the level of tomato resistance to this insect pest by the mechanism of antixenosis or non-preference.

The genotypes with high zingiberene contents in the leaves and greater average number of type IV and type VI trichomes were effective in causing an antibiotic effect in the development of $H$. armigera, but at a lower 
level than wild accession 'PI-127826', since the larvae fed with leaves of this genotype did not enter the pupal stage. This may be due to 'PI-127826' has higher contents of zingiberene in the leaves and greater average number of glandular trichomes than the selected genotypes.

Silva et al. (2016) and this study verified an association between the increase of the level of resistance by the mechanism of antixenosis and antibiosis in the development of $\mathrm{H}$. armigera fed with leaflets of genotypes with the highest densities of type IV glandular trichomes, coming from the crossing of the tomato with the wild accession 'LA-1401' of $S$. galapagense.

Resistance caused by zingiberene and type IV and type VI glandular trichomes, both via antixenosis and antibiosis has also been reported for other important pests of the tomato crop, such as tomato pinworm Tuta absoluta (Oliveira et al., 2012), the whitefly Bemisia tabaci (Silva et al., 2009), the two-spotted spider mite Tetranychus urticae (Gonçalves et al., 2006), among others.

Lima et al. (2015) found high estimates of heritability for the content of zingiberene in the leaves and found the level of this allelochemical is controlled by two genes with incomplete dominance in the sense of lower content, using populations from the crossing of the Redenção variety with accession 'PI-127826'. This may reflect satisfactory genetic gains over the backcrossing over generations, using the indirect selection for resistance to arthropods pest based on zingiberene contents. Indirect selection facilitates the selection process, are done directly in the field or laboratory, but in most cases, it is not feasible in large plant populations such as the segregating populations.

\section{CONCLUSION}

In general, the indirect selection of tomato genotypes for the zingiberene allelochemical content and high density of type IV and type VI glandular trichomes in the segregating generation of the first backcross for the Redenção variety was efficient to obtain genotypes with higher resistance levels to $\mathrm{H}$. armigera, both by the mechanism of antixenosis and by the antibiosis. The selected genotypes are promising to continue the tomato-breeding program, aiming to obtain tomato genotypes with characteristics desirable for industrial processing and resistant to $H$. armigera.

\section{REFERENCES}

Andrade MC, Silva AA, Neiva IP, Oliveira IR, et al. (2017). Inheritance of type IV glandular trichome density and its association with whitefly resistance from Solanum galapagense accession LA1401. Euphytica. 213: 1-12. https://doi.org/10.1007/s10681-016-1792-1.

Baier JE, Resende JT, Faria MV, Schwarz K, et al. (2015). Indirect selection of industrial tomato genotypes that are resistant to spider mite (Tetranychus urticae). Genet. Mol. Res. 14: 244-252. https://doi: 10.4238/2015.January.16.8.

Bleeker PM, Mirabella R, Diergaarde PJ, Van-Doorn A, et al. (2012). Improved herbivore resistance in cultivated tomato with the sesquiterpene biosynthetic pathway from a wild relative. Proc. Nat. Acad. Scie. Unit. Sta. Ame. 49: 20124-20129. http://doi.org/10.1073/pnas.1208756109

Carter CD, Sacalis JN and Gianfagna TJ (1989). Zingiberene and resistance to Colorado potato beetle in Lycopersicon hirsutum $\mathrm{f}$. hirsutum. J. Agric. Food Chem. 37: 206-210.

Czepak C, Albernaz KC, Vivan LM, Guimarães HO, et al. (2013). Primeiro registro de ocorrência de Helicoverpa armigera (Hübner) (Lepidoptera: Noctuidae) no Brasil. Pesq. Agrop. Trop. 43: 110-113. http://dx.doi.org/10.1590/S1983-40632013000100015.

Dias DM, Resende JTV, Marodin JC, Matos R, et al. (2016) . Acyl sugars and whitefly (Bemisia tabaci) resistance in segregating populations of tomato genotypes. Genet. Mol. Res. 15: 01-11. https://doi:10.4238/gmr.15027788 .

Ferraz E, Resende LV, Lima GSA, Silva MCL, et al. (2003). Redenção: nova cultivar de tomate para a indústria resistente a geminivírus etospovírus. Hortic. Bras. 21: 578-580. http://dx.doi.org/10.1590/S0102-05362003000300033.

Ferreira DF (2008). SISVAR: Um programa para análises e ensino de estatística. Rev. Cient. Symp. 6: 36-41. 
Freitas JA, Maluf WR, Cardoso MG, Gomes LAA, et al. (2002). Inheritance of foliar zingiberene contents and their relationship to trichome densities and whitefly resistance in tomatoes. Eupytica. 127: 275-287. https://doi.org/10.1023/A:1020239512598.

Glas JJ, Schimmel BC, Alba JM, Escobar-Bravo R, et al. (2012). Plant glandular trichomes as targets for breeding or engineering of resistance to herbivores. Inter. Jour. Mol. Scie.13:17077-17103.

Gonçalves LD, Maluf WR, Cardoso MG, Resende, JTV, et al. (2006). Relação entre zingibereno, tricomas foliares e repelência de tomateiros a Tetranychus evansi. Pesq. Agropec. Bras. 41: 267-273. http://dx.doi.org/10.1590/S0100-204X2006000200011.

Greene GL, Leppla NC, Dickerson WA, (1976). Velvetbean caterpillar: a rearing procedure and artificial medium. Jour. Econ. Entom. 69: 487-488 1976. https://doi: 10.1093/jee/69.4.487

Kraus JE, Arduim M, (1997). Manual básico de métodos em morfologia vegetal. Seropédica: EDUR 221p.

Labory CRG, Santa-Cecília LVC, Maluf WR, Cardoso CG, et al. (1999). Seleção indireta para teor de 2-tridecanona em tomateiros segregantes e sua relação com a resistência à traça-do-tomateiro. Pesq. Agropec. Bras. 34: 733-740. http://dx.doi.org/10.1590/S0100204X1999000500002.

Lima IP, Resende JTV, Oliveira JRF, Faria MV, et al. (2015). Indirect selection of industrial tomato genotypes rich in zingiberene and resistant to Tuta absoluta Meyrick. Genet. Mol. Res. 14: 15081-15089. http://dx.doi.org/10.4238/2015.November.24.16.

Lucini T, Faria MV, Rohde C, Resende JTV, et al. (2015). Acylsugar and the role of tricomes in tomato genotypes resistence to Tetranychus urticae. Arthopod-Plant Interact 9: 45-53. https://doi.org/10.1007/s11829-014-9347-7.

Luckwill LC (1943). The genus Lycopersicon, an historical, biological, and taxonomic survey of the wild and cultivated tomatoes. Aberdeen University Studies, Scotland.

Maluf WR, Campos GA and Cardoso MG (2001). Relationships between trichome types and spider mite (Tetranychus evansi) repellence in tomatoes with respect to foliar zingiberene contents. Euphytica 121: 73-80. https://doi.org/10.1023/A:1012067505361.

Mamta K, Reddy RK and Rajam MV, (2016). Targeting chitinase gene of Helicoverpa armigera by host-induced RNA interference confers insect resistance in tobacco and tomato. Plant. Mol. Biol. 90: 281-292. http://dx.doi.org/10.1007/s11103-015-0414-y.

Muthukumaran, N, (2016). Biophysical and biochemical factors of resistance in tomato accessions as influenced by selected bioinoculants against fruit worm Helicoverpa armigera (Hübner). Inter. Jour. Cur. Micro. Appl. Sci. 5:252-262.

https://doi.org/10.20546/ijcmas.2016.501.024

Oliveira CM, Andrade Junior VC, Maluf WR, Neiva IP, Maciel GM, (2012). Resistance of tomato strains to the moth Tuta absoluta imparted by allelochemicals and trichome density. Ciên. e Agrotec, 36, 45-52. http://dx.doi.org/10.1590/S141370542012000100006

Pratissoli D, Lima VLS, Pirovani VD and Lima WL, (2015). Occurrence of Helicoverpa armigera

(Lepidoptera: Noctuidae) on tomato in the Espírito Santo state. Hortic. Bras. 33: 101-105. http://dx.doi.org/10.1590/S0102053620150000100016

Resende JTV, Maluf WR, Cardoso MG, Gonçalves LD, et al. (2009). Resistance of tomato genotypes to the silverleaf whitefly mediated by acylsugars. Hortic. Bras. 27: 345-348. http://dx.doi.org/10.1590/S0102-05362009000300015

Roditakis E, Steinbach D, Moritz G, Vasakis E, et al. (2017). Ryanodine receptor point mutations confer diamide insecticide resistance in tomato leafminer, Tuta absoluta (Lepidoptera: Gelechiidae). Insect. Biochem. Mol. Biol. 80: 11-20.

https://doi.org/10.1016/j.ibmb.2016.11.003.

Safuraie-Parizi S, Fathipour Y, Talebi AA, (2014). Evaluation of tomato cultivars to Helicoverpa armigera using two-sex life Table parameters in laboratory. Jour. Asia-Pacif. Entom., v.17, p.837-844, 2014. https://doi.org/10.1016/j.aspen.2014.08.004

Sharma H C, Dhillon MK, Arora, R (2008). Effects of Bacillus thuringiensis $\delta \delta$-endotoxin-fed Helicoverpa armigera on the survival and development of the parasitoid Campoletis chlorideae. Ento. Expe. Appli, 126, 1-8.

Silva AA, Andrade MC, Carvalho RC, Neiva IP, et al. (2016). Resistência à Helicoverpa armigera em genótipos de tomateiro obtidos do cruzamento de Solanum lycopersicum com Solanum galapagense. Pesq. Agropec. Bras. 51: 801-808. https://doi.org/10.1590/S0100204X2016000700002.

Silva VF, Maluf WR, Cardoso MG, Gonçalves Neto AC, et al. (2009). Resistência mediada por aleloquímicos de genótipos de tomateiro à mosca-branca e ao ácaro-rajado. Pesq. Agropec. Bras. 44: 1262-1269. http://dx.doi.org/10.1590/S0100-204X2009001000008. 
Resistance to Helicoverpa armigera mediated by zingiberene and glandular trichomes in tomatoes for industrial processing

Talekar NS, Opeña RT, Hanson P, (2006). Helicoverpa armigera management: a review of AVRDC's research on host plant resistance in tomato. Cro. Prot. 25: 461-467. https://doi.org/10.1016/j.cropro.2005.07.011

Tay WT, Soria MF, Walsh T, Thomazoni D, et al. (2013). A brave new world for an old world pest: Helicoverpa armigera (Lepidoptera: Noctuidae) in Brazil. Plos One, 8: 1-7. https://doi.org/10.1371/journal.pone.0080134.

Usman A, Khan IA, Inayatullah M, Saljoqi AUR, et al. (2013). Appraisal of different tomato genotypes against tomato fruit worm (Helicoverpa armigera Hub.) infestation. Pakistan J. Zool. 45: 113-119. 